\title{
Body-hacking: On the Relationship between People and Material Entities in the Practice of Technological Body Modifications
}

\author{
JANA KADLECOVÁ*
}

Body-hacking: O vztahu lidí a materiálních entit v praxi technologických modifikací těla

\begin{abstract}
The text focuses on a critical reflection on research conducted among Czech bodyhackers and, in general, on the possibilities and limitations of the conceptualization of the body, which is a product of technohuman interconnections, in socialscientific research. This issue logically directs me towards theoretical and conceptual foundations of symmetrical anthropology taking into account the role of nonhuman actors and the materiality of the world (based on the works of Bruno Latour, John Law, etc.) which constitute the core of the text. This study critically reflects upon the traditional foundations of social sciences that deal with an individual's subjective perspective when studying corporeality. This leads to a reproduction of the dichotomy of subject/ object and body/mind which are revealed as restrictive in the research of technological modifications and cybercorporeality in general and require a clear definition of the concepts of the "body" and "technologies" that are, however, limiting from the point of view of the lived experience of their users. The question arises of where the human body ends and technologies begin, whether the human body in its "natural" state has a certain integrity. This approach is demonstrated in the text on the case of Czech body-hackers, the NFC chip users.
\end{abstract}

Keywords: Body-hacking; corporeality; technology; body modifications; symmetrical anthropology; posthumanism; non-human actors

DOI: $10.14712 / 23363525.2020 .4$

\section{Introduction}

Rapid progress in the area of science and technology in the twentieth century has had a great impact on Western post-modern culture and society and has resulted in a transformation process that can be called cyborgization of man, i.e. man is more and more interconnected with various technological extensions [cf. Hayles 1999; Macek 2003]. This transformation is most clearly apparent in the area related to the human body and the practices of biomedicine applied to it. It is, of course, information technologies that also have areat impact on the understanding of corporeality, which can be seen in, for example, the ways of selfrepresentation in cyberspace. Technologies provide people with the possibility to improve their "imperfect" bodies so that they are highperforming and comply with cultural standards, as there are higher demands placed on them and they become subject to more and more control [Foucault 1999; see Lupton 2014; Sanders 2017] for empirical studies on this topic]. Technologies represent, however, a possibility of choice and a challenge to

\footnotetext{
* Mgr. Jana Kadlecová, Department of Sociology, Andragogy and Cultural Anthropology, Faculty of Arts, Palacky University, Kř́žkovského 511/8, 77147 Olomouc. E-mail: jana.kadlecova03@upol.cz
} 
not only cultural standards of appearance of the body but also to traditionally established categories of the natural and the artificial [Haraway 1991].

The clash between the two above-mentioned influences is shown clearly and particularly in the practice of bodyhacking. This term is used at present for quite an extensive range of body alterations aimed at the improvement of or extension of human abilities. These modifications can be accomplished in various forms, with the most frequently technological body modifications including 3D printed prosthetics, electronic microchips in hands, or cameras instead of eyes. The technologies meant here are both medical and compensational as well as modifications functionally extending human abilities beyond the limits of human capabilities as a species. An important factor is that these body modifications are carried out outside conventional health care and on a voluntary and experimental basis. This means that these modifications are not considered common, contradicting established standards and raising controversy [see Duarte 2014; Dudziaková 2014; Kadlecová 2017; PittsTaylor 2003].

Bodyhacking ranks among methods of body art that became popular in the 1990s. At that time, there was a revival of modifications typical for many non-Western societies and their appropriation within the societies of the West (e.g. so called "modern primitive" subculture) where they represented the same symbolic control over the body and challenge to standards as happens with bodyhacking [PittsTaylor 2003: 23-48]. In the case of bodyhacking, however, the concept of the body moves to yet another level than aesthetic or symbolical. The phenomenon of functional modifications appeared for the first time in the late $1990 \mathrm{~s}^{1}$ and gradually developed mostly in the form of an underground contra-culture characterized by a strong individualism and activism. Simultaneously, however, with these individual and in most cases extreme body projects, some biotechnology enthusiasts tried to introduce these kinds of body modifications as a safe and to a certain extent useful procedure available for anyone. ${ }^{2}$ Thanks to this, functional implants such as, for example, NFC chips $^{3}$, found their supporters among the general population as well, even though it is still a rather peripheral phenomenon. Its users are no longer only devotees of extreme body modifications or fans of cyberpunk, but also people who otherwise do not favour body modifications all that much.

The above-mentioned NFC implants have also gained popularity in the Czech Republic. One could read in the media about actual users of these chips for the first time in 2016 who publicly admitted having the implant and when two group and open to the public implantations of the device in people's bodies took place in Prague. In my research I focused on this kind of functional modification and its users [Kadlecová 2017]. It is the first empirical research of this cultural phenomenon in anthropology in the Czech Republic, however, its extent was not sufficient for deeper exploration and can be understood as an initial insight into the issue.

1 There are several persons considered the first user of a silicon chip inside the body. One of them is Kevin Warwick [Warwick 2016], while another one is the founder of the "body hacktivism" movement Lukas Zpira [Duarte 2014: 278].

2 As an example might serve companies called Dangerous Things or Cyborg Nest among many that are developing, producing and distributing various implants, making it accessible also for the public.

3 NFC chips are a type of implant that enables to store data, such as identification keys, and through wireless connection can communicate with various technological devices, similarly to identity or credit cards. I elaborate more on this type of "body-hack" in the second part of the study. 
It might seem that the term bodyhacking (or technological body modifications) itself, through the words it consists of, creates the frame for what the subject of the presented research is, that being specific transformation of human corporeality by means of technologies under the baton of the socio-cultural context. The text presented here aims to reflect, however, upon this approach and point out the limits of the traditional social constructionist approach to the study of the human body. The study is based on ethnographic research among users of the above-mentioned electronic NFC chips in the Czech Republic conducted in 2016 and 2017 for a Master's thesis. The results of this research, as well as a huge number of contemporary social scientific research projects dealing with the topic of the body or technologies, demonstrate the complexity of the area which is resistant to either a simple description or even attempts for its unambiguous specification. The research into the above-mentioned areas of human life represents a far greater challenge and will not be possible without problematization of these terms and the reality that the joining of these two areas represents.

\section{The Hybrid Nature of Corporeality}

Bruno Latour in his book published in the early 90's explains the modern age of Western, science powered societies as based on a fictional dualism between nature and culture. This distinction is further reproduced through a reallocation of certain phenomena to one or the other area, which requires "purification" of the individual phenomena, assigning unambiguous attributes and affiliations to them [Latour 1993]. Tighter ties between humans and their own technoscientific creations make the hybrid nature of reality much more visible, in other words, the individual elements of these interconnections more and more resist to such a purification. Anthropological research then gradually begins to accept the idea that this distinction, based on clear definitions of the order of nature and culture, is rather reductionist [see Descola 2014; Ingold 2000; Kohn 2013].

In this case, a solid starting point for the studies of technological modifications is reviewing the terms we use to describe the examined phenomenon and thinking of what joining together the words "body" and "modification" imply for the selection of the theoretical and conceptual foundations of the work [cf. Duarte 2013]. This reflection, however, brings up the question of how to talk about these two aspects of human life in another way and whether the conceptual vocabulary provided by traditional social-scientific research is suitable for this task at all. The latest (bio)technologies and their impact on humanity and their lives bring into focus a more general question about what the relation of human beings to the material world is and whether the understanding of material and nonhuman entities as mere objects does not leave out certain important elements in this equation.

Under the influence of Science, Technology and Society studies (STS) and what can, in general, be called "posthuman turn" in social sciences, the relations between humans, technologies, society/culture, and nature can be understood from a different point of view. Mike Michael points out that "[t]here are no humans in the world" [2000: 1], at least not in the sense we are used to thinking about them [cf. Foucault 1994; Braidotti 2017]. By means of this statement he encourages readers to abandon the essentialist concept of humanity ${ }^{4}$

4 This idea is promoted in anthropology by, among others, Tim Ingold [Ingold - Pálsson 2013] or Eduardo Kohn [Kohn 2013]. 
as a clearly defined and delimited entity that exists per se and, instead, leads to thinking about humanity as a product of not only language and discourse formations but also (and primarily) mutually interacting elements, both technological and natural, across heterogeneous networks consisting of humans and nonhumans. The same holds true for every part of such formations, i.e. also nature, animals and technologies.

A product created in this way is by no means an ultimate result, being an unfinished dynamic process, which is the reason why the terms humans and nonhumans in contemporary socioscientific discourse are more and more frequently replaced by concepts such as streams, movements, arrangements, etc. Relations and bonds between entities consequently play a key role, yet not only in the sense of relations within the socio-cultural context (as traditionally seen by, e.g., the perspective of social or cultural constructionism). The essential foundation of the alternative approach is the theoretical-conceptual approach of the already mentioned Bruno Latour, ${ }^{5}$ who encourages us to abandon the humanistic concept of "society" as a special sphere of reality belonging to humans only. If we want to encompass the relations of humans to nonhuman and material entities in all their complexity, we should think about "the social" as a collective and heterogeneous assemblage of diverse entities [Latour 2005; cf. Law 2004; Haraway 1991; Serres - Latour 2008].

Bodyhacking as a phenomenon is a result (or better said an unfinished process) of the cointeraction of seemingly incomparable areas: technologies, bodies and humans. There is no other phenomenon that would represent hybridity and heterogeneity more explicitly, this being a model example of the coexistence of human and non-human entities the product of which are cyborgs - not only metaphorical ones but also the real ones. Nevertheless, when we talk about the heterogeneity of reality, we raise a question at the same time as to how it is possible to encompass and explore these disparate entities, relations and processes that constitute this heterogeneity [cf. Michael 2000].

The contribution of my own research in this area, as the starting point, lies in the fact that it has revealed the limitations of the originally selected perspective I used when approaching the subject [see Kadlecová 2017]. The main task of the presented research was to determine what the concept of corporeality among bodyhackers is like. Traditional cultural constructivism, which tries to reveal the "web of meanings" in which the actors are hung up and which structure their actions [Geertz 2000: 15; cf. Hess 1997: 83], proved to not be exactly faulty but, nevertheless, insufficient for the description of the complexity of the researched phenomenon. A problem arises related to both the actors and the reality that defines this web of meanings. Attempts at an analytical purification of the phenomena and a search for the central directing principle that would explain this reality not only extremely reduces the problem, it also proves to be an unattainable goal. The diversity of various concepts of the body itself and corporeality in general, the plurality of the meanings that are attributed to the modifications and opinions and motivations of the individual participants, the fluid border between the natural and the artificial, that sometimes seem to be firm, sometimes completely absent, and the heterogeneous nature of the group of bodyhackers, resisting being conceived as a clearly defined community [Kadlecová 2017;

\footnotetext{
5 Bruno Latour is mentioned here because he is one of the most significant proponents of the above-mentioned approach. He is, of course, by far not the only one, e.g. John Law, Michel Serres, Donna Haraway, and many others could be mentioned here.
} 
cf. Duarte 2013: 19-20], these unclear results of the primary research only point out the limitations of the selected perspective which is being critically reflected upon here. An alternative approach to the conceptualization of the body as a techno-human assemblage will be considered and demonstrated using empirical material in the second part.

\section{The Body in Anthropology as a Problem}

In contemporary social-scientific research, the body from a theoretical point of view is a real nut to crack. Thomas J. Csordas in the introduction to his article devoted to the anthropology of the body states: "The body has always been with us in cultural and social anthropology, but it has not always been a problem" [1999: 172]. By this he suggests that in relation to the body we can speak, in terms of anthropology, about its "career" as it has been gradually changing in status in both ethnographic research and theoretical thinking. The concept of the body as an object, a biological base which is the object of cultural appropriation, has developed gradually towards discerning the bidirectional relationships between the body and socio-cultural or political context [e.g. Blacking 1977; Douglas 1996; Foucault 1999] and to the latest reflections on the "embodiment" (i.e. the body as a place of subjective experience [e.g. Csordas 1994]) or its reconceptualization in relation to other human and nonhuman entities and the surrounding reality of heterogeneous formations [e.g. Latour 2004].

Thinking about the body has to be placed into a wider context. As has already been mentioned above, the way of its conceptualization is closely related to the concept of science as such. The tradition of modernity that taught us to think in dualist categories enabled the division of reality into the domain of objective and unchangeable nature and the domain of subjective sociocultural representations. In doing so, it established the status of Western science which is able to see existing reality independently and explain it truthfully that is objectively [Latour 1993; 2004]. In the case of the body, the tradition of modernity tempts us to think of the body from a physiological point of view as the object of interest of medicine and, correspondingly to this, about its cultural appropriation [Scheper-Hughes - Lock 1987: 8-11]. One is then forced to see the body either in the spirit of cartesianism, thinking of the spirituality and materiality of the body as two separate essences, or one has to accept phenomenology and give a nod to a subjective embodied experience, which, according to some scholars, prevents the body from the possibility of being in any way at all objectively or scientifically knowable [Latour 2004: 224].

Now, let us return back to the pioneering attempts to introduce the body as an object of interest in anthropology and related socio-scientific disciplines, and look at which approaches have been reproduced during these conceptualizations. A celebrated study by Marcel Mauss, Techniques of the Body [1973], is valuable for taking into account the historical and cultural changeability of the human body. In another work, however, on individual personality he replicates thoughts of the Cartesian dualism of separate domains of mind and matter [Csordas 1999: 175]. Through the works of Mary Douglas, we learn about the concept of "two bodies", social and physical ones [Douglas 1996], which is based on the Durkheimian concept of "the social" as an area outside other areas of lived reality (nature, technology), this being then a concept that Latour would undoubtedly take a critical stance towards. Nancy Scheper-Hughes and Margaret Lock then come with "three 
bodies" - individual, social, and political ones - by this moving closer to overcoming the dualism of the body and the mind [Scheper-Hughes - Lock 1987], although they are still advocates of thinking in terms of distinctions. A bidirectional relationship between the biology of humanity and culture is then taken into account by John Blacking [1977], who promotes the approach that the body and the mind cannot be separated.

A great deal of research, however, into corporeality in indigenous societies has turned attention to the fact that these concepts of Western science cannot be universalized. The body in its natural form is unthinkable, with the essentialist concept of the body having been denied already by the thinkers of the postmodern, feminism and post-structuralism. The body is always directly negotiated within specific cultural-historical-geographic circumstances, and also the idea of the natural body is a socio-cultural construct, as Judith Butler states in the case of sexuality, which means it is constituted discursively [Butler 1993]. Anthropological findings about other societies provide evidence of the fact that the "natural body" may have many forms often opposed to the concept of Western societies. Csordas in his article uses the example of the research on the Maoris by Paul Radin or Leenhardt's ethnographic study of the tribe Do Kamo in Melanesia [Csordas 1999: 173-175]. Leenhardt made a discovery comparable to contemporary "ontologists" [see Holbraad - Pedersen 2017] when he realized how stereotypical and fallacious it is to understand the body as a part of nature as opposed to the concept of mind which is deemed to be a product of culture and civilized way of living. By contrast, it turned up that it is the body to which local people had not acknowledged its specific existence until this notion was imported to them through European cultural expansion [Leenhardt 1979]. This example demonstrates that the idea of the body as something that has its own existence being specific for Western "ontologies". It is the very idea of the material body that enables its objectivization and leads to the discrimination of other important aspects of corporeality. The objective of this reflection then is by no means to deny the material essence of the body, but rather to demonstrate that there is not one single way to understand the body, not even within the history of Euro-American society [Harris Robb 2012: 670; cf. Latour 2004].

The authors Oliver Harris and John Robb have attempted to deal with the tendencies in contemporary anthropology and explain the local perspectives of corporeality better with ontological than epistemological differences; thinking about how to understand various seemingly incomparable views of the human body. In their own words, "the body is always ontologically multimodal. In all societies, people understand it and experience it according to several sets of foundational principles that come into play in different circumstances and that sometimes exist in tension. These contexts are neither simply social nor material but, rather, always already both" [Harris - Robb 2012: 676].

Thinking in multimodality is nothing else than taking into account socio-material contexts in which specific "bodies" emerge. This approach avoids both naturalism, i.e. the idea of the existence of the ahistoric biological nature as a determining factor, and social constructivism that conceives reality as separate from nature and as its representation only [an approach demonstrated by, e.g. Shilling 2003]. Ontologies are not determined directly, however, by the materiality of the world, but are, nevertheless, constituted depending on it, while it is not possible to determine clear-cut boundaries between human and non-human entities [see Latour 1994; 2004; 2005; cf. Barad 2003]. 
However, it is not only indigenous non-Western societies that serve as a source of a different "ontological" thinking about corporeality. The need to reflect upon the human body in a new way in relation to non-human and material entities appears at the centre of Western society hand in hand with the technological progress that makes the interconnections between humanity and technology more visible than at any other time in the past. In the area of social sciences, these issues have received significant reflection [see Hayles 1999; Martin 1992]. A way out of the hegemony of social discourse about a universal natural body is presented by Donna Haraway, among other things, through the use of the concept of a "cyborg" and the related ethical and political implications [Haraway 1991]. In her opinion, there is a need to initiate "politically engaged attacks on various empiricisms, reductionisms, or other versions of scientific authority" [Haraway 1991: 194], which means casting doubt on biological essentialism and conceptual dualism. With the use of the metaphor of the hybrid identity of a cyborg, she problematizes the boundaries between humans and animals, between living and non-living entities.

Phenomenology also approaches dualism in the conception of corporeality critically and also provides the foundation for the concept of "embodiment" used by the already mentioned Thomas J. Csordas. This concept presents the view of the body or corporeality as the basis for perception processes that end with objectivization but where the body is not an object in and of itself. It is a source of subjective or inter-subjective experience, which means, in a Heideggerian sense, our "being-in-the-world" [Csordas 1999: 181] The objectivization of the body is the product of ideological knowledge only, be it in the form of colonial Christianity, the natural sciences and medicine of the nineteenth century, as Michel Foucault states in his work The Birth of the Clinic [2010], or the culture of consumption [Csordas 1994: 7]. "Embodiment" - subjective corporeal experience - is then a mere prerequisite for even the possibility of perceiving anything such as objects at all and creating representations. Csordas then also presents this concept as the foundation for anthropological studies of culture [Csordas 1990; 1994].

Although the concept of "embodiment" is critical of traditional Cartesianism, it is still based on the modernist "asymmetrical bifurcation of the world" [Webmoor - Witmore 2008: 57], the duality of an object and a subject. This is why the phenomenological approach is the object of Latour's criticism. He states that if we use a model where the world of nature is an object, the body is a subject and language is the mediator of the interconnection between these two domains, we will again end up with reality divided in two: one that is knowable through objective science only and the other one that exists in an individual's mind only as a cultural construct. Latour thereby points out that there is no space in this model for the body and it disappears. It is not only insufficient for the description of the dynamics of corporeality, but also highly problematic as it leads to the classification of the representations of reality into more exact ones and less exact ones, which is normative in principle [Latour 2004: 208-209].

However, the concept of "embodiment" inspired by phenomenology carries a great significance for current posthuman critical theory. In contrast to the notion of fixed "body-object", the embodiment is a historical, situated and contextual experience, "enmeshed within the specifics of place, time, physiology, and culture, which together compose enactment. Embodiment never coincides exactly with 'the body"' [Hayles 1999: 196], because it is capable of realization far beyond the boundaries of "body-object" as an organism closed 
by the skin. What if is this skin, or even body organs, disrupted by some kind of intervention, operation or modification: To what extent is the concept of body sufficient, when one of its constitutive conditions, integrity, is called into question? The technologically modified body makes the ability of externalization of human embodied experience even more visible, and by that are the concepts of the external and internal sphere as well as firstand third-person perspectives questioned [Wegenstein 2010: 21]. Individuals materialize in various socio-material configurations and performative processes, take many different hybrid and decentralized shapes and engage in many "alternative forms of embodiment" [Ferrando 2014: 2019], that of digital avatars, media images, cybernetic organisms or genetically modified children, etc. The term "body" is evidently unfit to describe the complexity of the current human corporeal condition.

\section{How to Talk about Body}

The dualism of modern science has left us with specific vocabulary that restricts the ways we can talk about the body, i.e. in the sense of something that we "have" or that we "are". Annemarie Mol and John Law suggest speaking about the body that we "do" [2004: 45], about the body as an actor (similarly, e.g. also Arthur Frank on the body as the "epitome of flux" [Frank 1991]) and prefer behaviour or action as superior to knowledge; they are more interested in capturing the dynamics than in a holistic description. Analogically to this, in the Introduction, I mentioned the implications carried by the designation of technological body modifications where the "body" belongs in the world of nature and "modification" in the world of culture [Duarte 2013: 23]. I consider the term bodyhacking more appropriate as it evokes a body that is flexible, dynamic and involved in the process of change and transformation.

The question about how to talk about the body is what Latour also asks, who presents a systematic analysis of how to think and conceptualize the body if we acknowledge that we are not modern and we want to also include non-human and material entities in the equation. The first step is to abandon any efforts to essentialize, to define the body as any kind of substance [Latour 2004: 206]. He defines corporeality in the following way:

[...] to have a body is to learn to be affected, meaning "effectuated", moved, put into motion by other entities, humans or non-humans. [...] [Body is] an interface that becomes more and more describable as it learns to be affected by more and more elements. The body is thus not a provisional residence of something superior - an immortal soul, the universal or thought - but what leaves a dynamic trajectory by which we learn to register and become sensitive to what the world is made of. [...] By focusing on the body, one is immediately - or rather, mediately - directed to what the body has become aware of. [Latour 2004: 205-206]

Thus, he is not trying to grasp and define in theory the body itself but rather the "body talk" [Latour 2004]. He demonstrates his concept using the example of people in the perfume industry, who learn to distinguish between a broader spectrum of smells. By practising, these specialists learn to have a nose that extends their world by smells that an untrained person cannot distinguish. Their new "body parts" are acquired simultaneously with registering new actualities ("world counter-parts"). Acquiring the body is then a process that produces not only sensory means but also the world perceived [Latour 2004: 
207]. In other words, as the body is learning to be sensitive to various impacts, more diverse impacts come into existence. "Reality and artificiality are synonyms, not antonyms" [Latour 2004: 213]. Instead of statements made about objective reality (which are exactly those that imply the normative nature of these statements), we should rather talk about "articulations", the number of which can be infinite. They do not contradict one another, none of them is more or less "true" because more diversities emerge at the same time as these articulations. He again demonstrates this with the example of the chemical industry and fashion where articulations of perfumes do something to the smells themselves [Latour 2004: 213]. With this concept of corporeality, Latour makes it possible to also introduce artificial and material entities into the equation, an approach which is a contribution to the study of the phenomenon of bodyhacking.

Latour's concept of "body talk" also brings other advantages. When studying bodyhacking, a question arises about the transformations of corporeality under the influence of contemporary technological implants. The efforts to find a clear definition of what the body is and what it is not for users of hightech implants, proved, however, to be infeasible within the boundaries of established categories of the living and the inanimate. The discourse of bodyhackers then, in this sense, is far from being coherent [Kadlecová 2017; cf. Duarte 2013: 39]. The same incomplete picture is provided by focusing on body modifications as a kind of social, cultural and symbolic investment. The conceptualization of the body as an assemblage of relations between heterogeneous entities, as a place of dynamic change, seems to be more appropriate as it makes it possible to capture a larger number of nuances. A body which is modified (especially when the modification is aimed at extending the sensory or receptive fields of an individual, but not necessarily) is a body that is open to new influences ("learns to be affected") and in this way brings new articulations [Latour 2004: 210-211; cf. Duarte 2014]. Technologies implanted in bodies then represent new elements extending the "body talk" and the world with new "counterparts" that are registered. They themselves are actors that create new "social" relations. As a conclusion, this posthuman perspective leads me not to deal with the body as the main actor in the body-hacking practices, but instead to address it as one of many actors in the heterogeneous assemblages that create various alternative forms of embodiment.

\section{Body-hacking and Alternative Forms of Embodiment: The Case of NFC Chip User's}

The objective of my research on the practice of bodyhackers in the Czech Republic was to answer the question on the transformations of corporeality under the influence of technological extensions. The results of the research showed, however, that these unconventional body technologies make it complicated to talk about the body unambiguously without falling into the trap of dualist distinctions. Society in the West uses its own concept of the "natural" body which is postulated on the basis of science and technologies, which subsequently undergo a cultural transformation [Rabinow 2005: 99]. This concept of naturality is normative and technological modifications do not fit in this definition. Information technologies have pervaded our everyday life to such a significant extent that we do not realise their impact any longer, while the boundaries between a human and a machine on a physical level - on the level of "biosociality" [Rabinow 2005] - are guarded more 
strictly, and their interconnection is still considered by many as unnatural, controversial or, at least, unusual.

Progress in the area of body alterations with the help of technology puts this ideal of the "natural body" under pressure, and the guarded boundary between the animate and the inanimate, the natural and the artificial gradually loses its clear contours. Slowly also the users of the implants themselves reflect critically on the dichotomy between the natural and technological bodies both in theory and in practice, understanding the difference between biology and technology as "given terminologically and artificially" [Karel J., interviewee statement, 30/10/2016], although many of them still reproduce the duality to a certain extent in their opinions. The majority of them, when speaking, both confirm and deny it, which is, I argue, a manifestation of the fact that they are unable to distinguish between artificially created concepts and the ways in which they (do not) experience these differences in their everyday lives.

Instead it seems more useful to talk about the body in relation to new articulations, that is new differences that are registered through the modified body. Let us apply this perspective to the example of NFC chips. On the basis of wireless communication, they enable transmit data stored in the chip, for example, a unique identification number. The transmission works only on a short distance, the chip must be put near the reading device. Therefore, they are usually implanted in the hand to be easily used [Warwick 2017: 63-65]. They can be applied for example to open doors instead of keys, to unlock computers or mobile phones or to pay in bitcoin currency. They allow their users to interact with the surrounding environment in a way they would not be able to without them. With their help, the user integrates into a specific environment through determining specific intentions and actions. In the words of the users, it is a technology that "gives them a new opportunity" and they want to have it because "it is a new quality of life" [Martin Z., interviewee statement, 29/10/2016]. In the words of another user, the chip in the body is similar to "a magical power", the technology in connection with the body is able to develop "some physical phenomena, or work with them, that the body simply cannot make" and in this way "it can do something extra" [Martin P., interviewee statement, 12/11/2016].

The chip is a unique identifier of an individual's identity, an extension allowing them to enter the world of ones and zeros; for this reason, they are also called "identity implants" [Warwick 2017: 63]. In this sense, they are a digital online identity, decentralized "second self" [see Turkle 2015]. These "avatars" are a representation of the user, or more accurately (with regard to the etymology of the word avatar) an incarnation of the individual in the digital sphere [Ferrando 2015: 220], however, with real impact also in the non-virtual world. These technologies co-create the hybrid space of material and digital reality, as Katherine Hayles [1999] characterizes the posthuman condition.

In this respect, the technology need not be physically integrated into the body, but so-called "wearables" (for example, a chip card that we carry in a wallet) also meet the description. This extended definition of the body is what Latour works with, who postulates that the instrument that determines the difference in the behaviour in response to a newly experienced reality is also part of an individual's corporeality. Unlike Kevin Warwick [2017] who focuses on technological extensions of humans not only in theory but mainly in practice, my opinion is that there is no need to connect the technology directly to the human brain to be able to call such an individual "transhuman" or "posthuman". 
Humans have already been altered by digital technologies. They have a huge impact on cognitive abilities and the experience of reality and corporeality, most of our social interactions being determined by technological extensions. They negotiate the interaction between human and nonhuman entities, taking part in creating social relationships as a material object [see Law 2007] and also co-creating what we consider to be the body.

Generally, we can say that these implants connect people with what lies "beyond" common human experience. Just as the NFC chips enable their users to engage with the digital sphere, other sensory implants, for example earthquake detector called Seismic Sense of body-hacker Moon Ribas [Sayej 2016] or the "eyeborg" antenna of Neil Harbisson [Warwick 2017: 65] enable the body-hackers to perceive stimuli, which are not perceivable by human sensory organs, and through that they move them closer to animal experiential world. Socio-material connections beyond what we consider to be the human sphere are created and the boundaries between humans and machines are blurred. This is why it is necessary to also focus our attention on the technologies themselves.

\section{Fluidity of Technologies}

If the objective is to point out the interlinking connections between human and nonhuman and material actors in the analysis of bodyhacking, there is a need to approach all the elements of this hybrid grouping in the same way. I am going to focus on the technology of the implants from the point of view provided by heterogeneous constructivism. Analogically to how the fluidity of the body can be understood, it is also possible to conceptualize technologies. This inspiring approach is demonstrated in a study by Annemarie Mol and Marianne de Laet [2000] dealing with the "fluidity of technologies" using the example of a water pump in Zimbabwe. They view technologies here as actors, although not in the same sense as actorship is traditionally understood in philosophy and sociology, i.e. as a privilege of a rational human being [Latour 1994: 33]. Here, an actor represents the opposite to a fixed entity [de Laet - Mol 2000: 226]. They present the view of technology as something more than just a set of material parts that serve a specific function intended by their creator. They abandon efforts at ultimate description of the form and functioning of a specific technology and, instead, recognise the "fluidity" of its boundaries. This does not mean, however, that we necessarily need to sink into vague ideas suggesting that technology can be just anything. The fluidity of boundaries does not mean their nonexistence, for as Mol and de Laet argue, technologies also only have "a limited set of configurations" [237].

Such an approach can also be applied to the NFC chip implants. Similar to the case of the water pump, the functionality of the implant is probably what is thematized in common discourse most frequently. At the same time, there is no clear answer to this question. First, there are many variants and adaptations of the implants, second, there are a whole range of functions that the implant can provide for its user. The chip itself is a passive piece of technology that does not have its own power source. It does not serve any function unless it is placed on the external device able to read the content recorded on the microchip. Its function is then defined by the type of data stored on it and there are countless possibilities of what it may be used for, as was already described above.

The technology of the chip and the intention of its user are not the only determinants, however, of the chip's functionality. It is also impossible to imagine the implant without 
a whole range of other entities, with which it not only gets in contact but which also constitute the implant. In bodyhacking it is impossible to think of the implant and the body separate from each other (even if the device is not inside one's body). The body always plays an important part as a case or a carrier and as such it can put limitations on the use of the implant. It is then important where the implant is inserted in the body. A popular area for implantation is the connective soft tissue between the thumb and the index finger on the left hand. This is an otherwise unutilized spot where the chip is protected from shocks and where it is easy to manipulate it. Several chip users have mentioned, however, the limitations they encountered, e.g. the scanner was not adapted for placing a hand on it because it was in a narrow space where a hand could not be inserted. There are also other factors related to the body as a case for the microchip, such as the biocompatibility of the materials, the success rate of the implantation procedure, or specific health limitations that determine the quality of the functioning of the implant.

Furthermore, we have already mentioned external scanning devices and mobile phones without which the implant is unusable. Many of the electronic chip users cannot, for example, use their implant due to the lack of an adequately developed infrastructure in their area (scanning devices in institutions) that would be ready for it. At present, most institutions do not allow uploading of identification codes into one's own chip. Another problem can arise at the moment when the scanning device is unable to detect the signal that is weakened by the tissue between the device and the chip.

As concerns the developed infrastructure, it is only the demand and pressure from the side of the community of chip users - bodyhackers that can resolve this problem, they being then another indispensable element of the implant's technology. Czech bodyhackers, however, do not represent a compact group. The individuals might know each other but they do not necessarily. They mostly share similar values, ideological or political views. Their "sociality" is constituted mainly by sharing the specific experience of using technological implants, as described above. Apart from the users themselves, we need to take into account another part of bodyhacking - the entire network of people directly or indirectly involved in the production, offer and distribution of the implants and in the implantation procedure. It is certain that the increased popularity of implants in the population and their spreading beyond the boundaries of subcultures keen on extreme body modifications has been caused by the systemization of the design, production and sales. Bodyhacking then, in most cases, is not the matter of an individual any longer, as the testing and development of functional body technologies are carried out collectively, be it through international conferences and professional development companies, or through web forums. All this enables the accumulation of knowledge and further progress. According to the statements of the respondents, each user perceives his or herself as part of technological development because each user, in fact, voluntarily undergoes an experiment on their own body. As one of the chip users states, "[t]hat is what the progress is all about. [...] Without someone starting to try it, nothing would be invented. [...] And that's what's important, yes, that there is a community of people who are talking about it, dealing with it, whether it's economic or technical stuff" [Dominik S., interviewee statement, 9/11/2016]. Through these practices, bodyhackers refuse to be passive subjects who are subject to the standards imposed by society or the authority of the government [Pitts-Taylor 2003: 155], but instead actively and creatively use technologies on their own terms. In conclusion, it is obvious that 
bodyhacking represents a truly broad phenomenon that does not end with just the body and many different associations can be traced if we focus also on the technological actors as mediators of specific experiences and behaviors, and as initiators of change.

\section{Conclusion}

In my research the original question concerning the transformations of the body through the influence of technologies, paradoxically led to the transformation of my view of the body and technologies as such. This text's objective was to critically reflect upon empirical data from research about Czech body-hackers and propose a new way of analysis from the point of view of conceptual approaches based on science and technology studies by Bruno Latour, John Law, Annemarie Mol and on other posthuman approaches that reflect upon entanglements and groupings of people, bodies and technologies instead of pursuing the goal of conceptualization of technology or the body itself. In the area of technological body extensions, a question arises about the dichotomy of nature and culture that cannot be clearly isolated from one other and it is not the objective of anthropological research to do so either [Kobes 2015]. The objective is to find associations between them, mutual relations. Technological extensions may be not of an organic nature, they are not be a part of the body originally, but their effects, the new perceptions they enhance the body with, clearly form their embodiment. It is therefore important to include them in the definition of the body. I finally come to the conclusion that with efforts to conceptualize the corporeality of bodyhackers, it is important not to limit oneself to the cultural constructivist approaches that simply observe the ways in which the culture inscribes in the body discursively but to take into account the communication based on nondiscursive encounters with inanimate entities.

\section{Acknowledgement}

This study was written with the support of the Ministry of Education, Youth and Sports, grant project IGA_FF_2018_023 (Social Sciences 2018).

\section{Bibliography}

Barad, Karen [2003]. Posthumanist Performativity: Toward an Understanding of How Matter Comes to Matter. Signs: Journal of Women in Culture and Society 28 (3): 801-831.

Blacking, John [1977]. The Anthropology of the Body. London; New York: Academic Press.

Braidotti, Rosi [2017]. Posthuman Critical Theory. Journal of Posthuman Studies 1 (1): 9-25.

Butler, Judith [1993]. Bodies that Matter: On the Discursive Limits of "Sex". New York: Routledge.

Csordas, Thomas J. [1990]. Embodiment as a Paradigm for Anthropology. Ethos 18 (1): 5-47.

Csordas, Thomas J. (ed.) [1994]. Embodiment and Experience: The Existential Ground of Culture and Self. Cambridge - New York: Cambridge University Press.

Csordas, Thomas J. [1999]. The Body's Career in Anthropology. In. Moore, Henrietta (ed.). Anthropological Theory Today. Cambridge - Malden, MA: Polity Press, pp. 172-205.

de Laet, Marianne - Mol, Annemarie [2000]. The Zimbabwe Bush Pump: Mechanics of a Fluid Technology. Social Studies of Science 30 (2): 225-263.

Descola, Philippe [2014]. Beyond Nature and Culture. Chicago - London: The University of Chicago Press. 
Douglas, Mary [1996]. Natural symbols: Explorations in Cosmology. London - New York: Routledge.

Duarte, Bárbara N. [2013]. The Body Hacktivism Movement: A Talk About the Body. PsychNology Journal 11 (1): 21-42.

Duarte, Bárbara N. [2014]. Entangled Agencies: New Individual Practices of Human-Technology Hybridism Through Body Hacking. NanoEthics 8 (3): 275-285.

Dudziaková, Máša [2014]. Kyberpunkové maso po česku: funkční kyberpunkové tělesné modifikace v České republice. In. Soukup, Martin (ed.). Tělo: Čichat, česat, hmatat, propichovat, řezat. Červený Kostelec: Pavel Mervart, pp. 151-179.

Ferrando, Francesca [2014]. The Body. In. Ranisch, Robert - Sorgner, Stefan L. (eds.). Post- and Transhumanism. An Introduction. Frankfurt am Main - New York: Peter Lang D, pp. 213-226.

Foucault, Michel [1999]. Dějiny sexuality. Díl 1: Vưle k vědění. Prague: Herrmann \& synové.

Foucault, Michel [1994]. The Order of Things: An Archaeology of the Human Sciences. New York: Vintage Books.

Foucault, Michel [2010]. Zrození kliniky. Červený Kostelec: Pavel Mervart.

Frank, Arthur [1991]. For a Sociology of the Body: An Analytical Review. In. Turner, Bryan - Hepworth, Mike - Featherstone, Mike (eds.). The Body: Social Process and Cultural Theory. London: SAGE Publications, pp. 36-102.

Geertz, Clifford [2000]. Interpretace kultur: vybrané eseje. Prague: Sociologické nakladatelství.

Haraway, Donna [1991]. Simians, Cyborgs, and Women: The Reinvention of Nature. New York: Routledge.

Harris, Oliver J. T. - Robb, John [2012]. Multiple Ontologies and the Problem of the Body in History. American Anthropologist 114 (4): 668-679.

Hayles, Katherine [1999]. How We Became Posthuman: Virtual Bodies in Cybernetics, Literature, and Informatics. Chicago, Ill.: University of Chicago Press.

Hess, David J. [1997]. Science Studies: An Advanced Introduction. New York: New York University Press.

Holbraad, Martin - Pedersen, Morten A. [2017]. The Ontological Turn: An Anthropological Exposition. Cambridge - New York: Cambridge University Press.

Ingold, Tim [2000]. The Perception of the Environment: Essays on Livelihood, Dwelling \& Skill. London New York: Routledge.

Ingold, Tim - Pálsson, Gísli (eds.). [2013]. Biosocial Becomings: Integrating Social and Biological Anthropology. New York: Cambridge University Press.

Kadlecová, Jana [2017]. Body-hacking na české scéně: Politika těla nositelů čipových implantátů. In. Soukup, Martin (ed.). Tělo 2.0: Hranice těla a podoby bolesti. Červený Kostelec: Pavel Mervart, pp. 99-120.

Kobes, Tomáš [2015]. Když se lidé mění ve lvy: Problém překladu. Teorie vědy 37 (3): 303-325.

Kohn, Eduardo [2013]. How Forests Think: Toward an Anthropology Beyond the Human. Berkeley: University of California Press.

Latour, Bruno [1993]. We Have Never Been Modern. Cambridge, Mass: Harvard University Press.

Latour, Bruno [1994]. On Technical Mediation. Common Knowledge 3 (2): 29-64.

Latour, Bruno [2004]. How to Talk About the Body? The Normative Dimension of Science Studies. Body \& Society 10 (2-3): 205-229.

Latour, Bruno [2005]. Reassembling the Social: An Introduction to Actor-Network-Theory. Oxford - New York: Oxford University Press.

Law, John [2004]. After Method: Mess in Social Science Research. London - New York: Routledge.

Law, John [2007]. Actor Network Theory and Material Semiotics. Retrieved from: <http://www. heterogeneities .net/publications/Law2007ANTandMaterialSemiotics.pdf> [15. 7. 2018].

Leenhardt, Maurice [1979]. Do Kamo: Person and Myth in the Melanesian World. Chicago: University of Chicago Press.

Lupton, Deborah [2014]. Critical Perspectives on Digital Health Technologies: Digital Health Technologies. Sociology Compass 8 (12): 1344-1359.

Macek, Jakub [2003]. Tělesnost a kyberkultura. Revue pro Média (5): 1-11.

Martin, Emily [1992]. The End of Body? American Ethnologist 19 (1): 121-140.

Mauss, Marcel [1973]. Techniques of the Body. Economy and Society (2): 70-88.

Michael, Mike [2000]. Reconnecting Culture, Technology and Nature: From Society to Heterogeneity. London; New York: Routledge. 
Mol, Annemarie - Law, John [2004]. Embodied Action, Enacted Bodies: The Example of Hypoglycaemia. Body \& Society 10 (2-3): 43-62.

Pitts-Taylor, Victoria [2003]. In the Flesh: The Cultural Politics of Body Modification. New York: Palgrave Macmillan.

Rabinow, Paul [2005]. Artificiality and Enlightenment: From Sociobiology to Biosociality. In. Inda, Jonathan X. (ed.). Anthropologies of Modernity. Oxford, UK: Blackwell Publishing, pp. 179-193.

Sanders, Rachel [2017]. Self-tracking in the Digital Era: Biopower, Patriarchy, and the New Biometric Body Projects. Body \& Society 23 (1): 36-63.

Sayej, Nadja [2016]. The World's First Cyborg Artist Can Detect Earthquakes with Her Arm. Vice, 23. 11. 2016. Retrieved from: <https://www.vice.com/en_us [20. 8. 2019].

Serres, Michel - Latour, Bruno [2008]. Conversations on Science, Culture, and Time. Ann Arbor, Michigan: University of Michigan Press.

Shilling, Chris [2003]. The Body and Social Theory. London; Thousand Oaks, Calif: SAGE Publications. Scheper-Hughes, Nancy - Lock, Margaret [1987]. The Mindful Body: A Prologomenon to Future Work in Medical Anthropology. Medical Anthropology Quarterly 1 (1): 6-41.

Turkle, Sherry [2005]. The Second Self: Computers and the Human Spirit. Cambridge, Mass.: MIT Press. Warwick, Kevin [2017]. A Practical Guide to Posthumans. Journal of Posthuman Studies 1 (1): 61-74.

Warwick, Kevin [2016]. Meet The Biohackers Letting Technology Get Under Their Skin. The Conversation, 27. 6. 2016. Retrieved from: <https://theconversation.com/uk> [11.11. 2018].

Webmoor, Timothy - Witmore, Christopher L. [2008]. Things Are Us! A Commentary on Human/Things Relations under the Banner of a "Social" Archaeology. Norwegian Archaeological Review 41 (1): 53-70. Wegenstein, Bernadette [2010]. Body. In. Mitchell, W. J. T. - Hansen, Mark B. N. (eds.). Critical Terms for Media Studies. Chicago - London: The University of Chicago Press, pp. 19-34.

Jana Kadlecová $\left({ }^{*} 1990\right)$ received her Master's degree in cultural anthropology from Palacký University of Olomouc, where is she currently studying for Ph.D. in the same discipline. Her main fields of interest are anthropology of the body, cyberanthropology and posthumanism, in her research she focuses on technological body modifications and Czech body-hacking scene. She is author of a chapter dedicated to this topic in a collective monography Tělo 2.0 (Soukup, M. ed., Pavel Mervart, 2017). 